\title{
Teichoic Acids and Group Antigens in Lactobacilli
}

\author{
BY M. ELISABETH SHARPE \\ National Institute for Research in Dairying, Shinfield, Reading \\ A. L. DAVISON AND J. BADDILEY \\ Department of Organic Chemistry, University of Newcastle upon Tyne
}

(Received 20 September 1963)

\begin{abstract}
SUMMARY
Purified teichoic acids and extracts with group-specific activity have been examined with specific antisera for a number of lactobacilli. The wall teichoic acids from groups $\mathrm{D}$ and $\mathrm{E}$ lactobacilli have been identified as the group-specific substances, whereas in group $\mathbf{A}$ the intracellular teichoic acid showed group-specificity. It is possible that group-specificity is associated with intracellular teichoic acid in group F.
\end{abstract}

\section{INTRODUCTION}

The teichoic acids are widely distributed in Gram-positive bacteria (Armstrong et al. 1958, 1959; Baddiley, 1961). Investigation of these polymers in Lactobacillus spp. and Staphylococcus spp. indicated that their presence within the cell wall of an organism was of taxonomic significance and could be correlated with serological behaviour (Baddiley \& Davison, 1961; Davison \& Baddiley, 1963). In staphylococci, ribitol teichoic acid containing $\beta$-glucosaminyl residues from walls of Staphylococcus aureus (Baddiley, Buchanan, RajBhandary \& Sanderson, 1962a; Baddiley, Buchanan, Martin \& RajBhandary, 1962b) is serologically indistinguishable from the group-specific precipitinogen, polysaccharide $\mathbf{A}$, of this organism (Haukenes, Ellwood, Baddiley \& Oeding, 1961; Haukenes, 1962), and glycerol teichoic acid containing glucosyl residues from walls of $\boldsymbol{S}$. saprophyticus (Davison \& Baddiley, 1963) is the group-specific precipitinogen, polysaccharide $\mathrm{B}$, of $\boldsymbol{S}$. albus (Morse, 1963). Moreover, the intracellular glycerol teichoic acid of group $D$ streptococci is the group antigen, and slight differences in behaviour of antigen preparations from different strains in group $D$ have been related to differences in chemical structure (Wicken, Elliott \& Baddiley, 1963).

In Lactobacillus spp. ribitol teichoic acid from walls of a strain of L. plantarum 17-5 contains both unsubstituted ribitol phosphate units and some to which one or two $\alpha$-glucosyl residues are attached (Archibald, Baddiley \& Buchanan, 1961), whereas in the intracellular teichoic acid from this organism and from a strain of L. casei var. rhamnosus only a small proportion of the glycerol phosphate moieties are substituted with glucose (Kelemen \& Baddiley, 1961; Critchley, Archibald \& Baddiley, 1962).

Although walls of many species of lactobacilli possess teichoic acids (Ikawa \& Snell, 1960; Baddiley \& Davison, 1961), those of groups B, C, F and G contain no teichoic acid, and it is of interest that Knox (1963) has recently shown that the 
specific antigens of groups $B$ and $C$ are serologically distinct cell-wall polysaccharides. However, the presence of teichoic acids in walls of group A, D and E indicates that the antigenic specific determinants of these groups could be their wall teichoic acids. The present investigation was undertaken in an attempt to relate directly the work on the composition of teichoic acids from Lactobacillus spp. with the serological classification of this genus (Sharpe, 1955b; Sharpe \& Wheater, 1957; Rogosa \& Sharpe, 1959), and to show that the immunological group-specificity of some of these organisms is related to the presence of teichoic acids.

\section{METHODS}

Preparation of teichoic acids. Lactobacilli were grown in batch culture (15 l.) in a liquid medium of the following composition : tryptone (Oxoid), 20 g.; yeast extract (Difco), 3 g.; sodium acetate, 10 g.; glucose, 20 g.; potassium dihydrogen phosphate, 4.5 g.; inorganic salts B (Barton-Wright, 1946), 5 ml.; oleic acid, $0.01 \mathrm{ml}$.; Tween 40, $1 \mathrm{ml}$; ; demineralized water, $1000 \mathrm{ml}$. Lactobacillus bulgaricus strain в 9 , L. helveticus NCIB 8025, L. jugurti NCIB 2889 and L. lactis NCIB 7278 were grown at $37^{\circ}$ for $16 \mathrm{hr}$, L. plantarum NCIB 7220 at $28^{\circ}$ for $16 \mathrm{hr}$, and L. brevis NCIB 8169 and L. buchneri NCIB 8007 at $28^{\circ}$ for $45 \mathrm{hr}$.

Bacteria were harvested in a refrigerated Sharples centrifuge, washed with cold $\mathbf{0} \cdot \mathbf{8 5} \%$ sodium chloride solution, the cell-wall and cytoplasmic-gel fractions isolated as previously described (Davison \& Baddiley, 1963) and residual cell cytoplasm from the group A species (Lactobacillus helveticus and L. jugurti) was preserved by freeze-drying.

The chemical composition of teichoic acids isolated by extraction with cold $10 \%(\mathrm{w} / \mathrm{v})$ trichloroacetic acid solution at $4^{\circ}$ was determined by hydrolysis with $2 \mathrm{~N}-\mathrm{HCl}$ or $2 \mathrm{~N}-\mathrm{NaOH}$ solutions for $3 \mathrm{hr}$ at $100^{\circ}$ and by examination of hydrolysates by paper chromatography as described in detail by Armstrong et al. (1958) and Archibald et al. (1961). Sugars and amino sugars were separated in aqueous propan2-ol (Smith, 1960) and in a mixture of pyridine + ethyl acetate + acetic acid + water (Fischer \& Nebel, 1956).

\section{Serological methods}

Preparation of antisera. Cultures for immunization were grown for $18 \mathrm{hr}$ in $40 \mathrm{ml}$. of MRS broth (de Man, Rogosa \& Sharpe, 1960) from which the meat extract had been omitted as being a substance likely to be adsorbed on to the organisms to be inoculated and to lead to the formation of antibodies against its components (Sharpe, 1955a). Temperatures of incubation and procedures for the preparation of antisera were those described by Sharpe $(1955 b)$. After the addition of thiomersalate $(0.01 \%)$ antisera were stored in $2.0 \mathrm{ml}$. portions at $-20^{\circ}$, apart from small samples for current work, which were kept at $4^{\circ}$. Antiserum for group A was prepared against Lactobacillus jugurti NCIB 2889, for group D against $L$. plantarum NIRD A 164, and for group E against L. lactis NCIB 7278.

Preparation of extracts. Organisms for extraction were grown for $48 \mathrm{hr}$ in $40 \mathrm{ml}$. of MRS broth from which the yeast extract had been omitted to prevent a nonspecific precipitin reaction with antibodies formed against it when preparing the group antisera. The extracts were prepared as described by Sharpe (1955b). Strains 
were representative from the collection of lactobacilli of one of the authors (M.E.S.); wherever possible, strains belonging to different serological types were used.

Ring precipitin tests. The method of Jones \& Shattock (1960) was used.

Gel-diffusion tests. The agar gel double-diffusion test of Ouchterlony (1953) was used.

Teichoic acid solutions. Concentrations of $1 \cdot 0,0 \cdot 1$ and $0.01 \mathrm{mg} . / \mathrm{ml}$. were used for the precipitin tests and $0.1 \mathrm{mg} . / \mathrm{ml}$. for the gel-diffusion tests. They were examined by these precipitin methods and their reactions compared with those of antigens which had been extracted by using $\mathbf{H C l}$. Samples from the same and additional strains belonging to the different serological groups of lactobacilli were compared.

\section{RESULTS}

Intracellular glycerol teichoic acid in the cytoplasmic-gel fraction of lactobacilli in groups $\mathrm{D}$ and $\mathrm{E}$ sedimented at $100,000 \mathrm{~g}$, but with the species in group $\mathbf{A}$ (Lactobacillus helveticus, L.jugurti) the teichoic acid was not isolated by ultracentrifugation, but remained in the residual cell cytoplasm. The composition of teichoic acids extracted from walls and cell cytoplasm is given in Table 1 . Walls of $L$. plantarum

Table 1. Origin, location and chemical nature of teichoic acids from different lactobacilli and staphylococcus

\begin{tabular}{|c|c|c|c|c|}
\hline Group A lactobacilli & Location & Type & Sugar & Alkali hydrolysis product \\
\hline L. helveticus NCIB 8025 & Wall & $\mathbf{G}$ & - & - \\
\hline & Intracellular & $\mathbf{G}$ & $\begin{array}{l}\text { Glucose (tr.) } \\
\text { Ribose (tr.) }\end{array}$ & Glucosylglycerol \\
\hline L. jugurti NCIB 2889 & Wall & $\mathbf{G}$ & 一 & 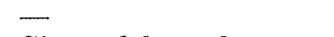 \\
\hline & Intracellular & $\mathbf{G}$ & $\begin{array}{l}\text { Glucose } \\
\text { Ribose (tr.) }\end{array}$ & $\begin{array}{l}\text { Glucosylglycerol } \\
-\end{array}$ \\
\hline \multicolumn{5}{|l|}{ Group D lactobacilli } \\
\hline L. plantarum NCIB 7220 & Wall & $\mathbf{R}$ & Glucose & $\begin{array}{l}\text { Mono- and di-glucosyl- } \\
\text { ribitol phosphates }\end{array}$ \\
\hline \multicolumn{5}{|l|}{ Group E lactobacilli } \\
\hline $\begin{array}{l}\text { L. buchneri NCIB } 8007 \\
\text { L. bulgaricus в } 9\end{array}$ & $\begin{array}{l}\text { Wall } \\
\text { Wall }\end{array}$ & $\begin{array}{l}\mathbf{G} \\
\mathbf{G}\end{array}$ & $\begin{array}{l}\text { Glucose } \\
\text { Glucose } \\
\text { Galactose }\end{array}$ & $\begin{array}{l}\text { Glucosylglycerol } \\
\text { Glucosylglycerol }\end{array}$ \\
\hline L. brevis NCIB 8169 & Wall & $\mathbf{G}$ & Glucose & $\overline{-}$ \\
\hline $\begin{array}{l}\text { L. Lactis NCIB } 7278 \\
\text { Staphylococcus epidermidis }\end{array}$ & $\begin{array}{l}\text { Wall } \\
\text { Wall }\end{array}$ & $\begin{array}{l}\mathbf{G} \\
\mathbf{G}\end{array}$ & $\begin{array}{l}\text { Glucose } \\
\text { Glucose }\end{array}$ & $\begin{array}{l}\text { Glucosylglycerol } \\
\text { Glucosylglycerol }\end{array}$ \\
\hline
\end{tabular}

(group D) contained a ribitol teichoic acid with mono- and di-glucosyl units. Strains of the different species in group $\mathbf{E}$ all possessed a chemically similar glycerol wall teichoic acid with glucosyl residues, whereas glycerol wall teichoic acid of the species in group A contained no sugar moieties.

Ring precipitin tests. Table 2 shows that the wall teichoic acid of Lactobacillus plantarum 7220 reacted with the antiserum for group $\mathbf{D}$ (prepared against a different strain, NIRD A 164) and that wall teichoic acids of the three strains in group $\mathbf{E}$ all reacted with the group $\mathbf{E}$ antiserum; but wall teichoic acids of the two strains in group A did not react with the specific group A antiserum. Cross-reactions with other group antisera were not observed, except for a weak cross-reaction between 
the teichoic acid from $L$. bulgaricus в 9 and group $\mathbf{D}$ antiserum. Specific reactions occurred with concentrations of $0 \cdot 1-0.01 \mathrm{mg} . / \mathrm{ml}$. teichoic acid.

With the intracellular teichoic acid preparations, material from both the strains of lactobacilli in group $\mathbf{A}$ reacted with the group $\mathbf{A}$ antiserum, and in addition a weak cross-reaction occurred between material from Lactobacillus jugurti 2889 and group $D$ and $E$ antisera. Preparations from L. lactis 7278 and L. buchneri 8007 also reacted with group $\mathbf{D}$ antiserum in addition to reacting to their own group $\mathrm{E}$ antiserum.

Table 2. Ring precipitin reactions of teichoic acid preparations with specific group antisera of lactobacilli

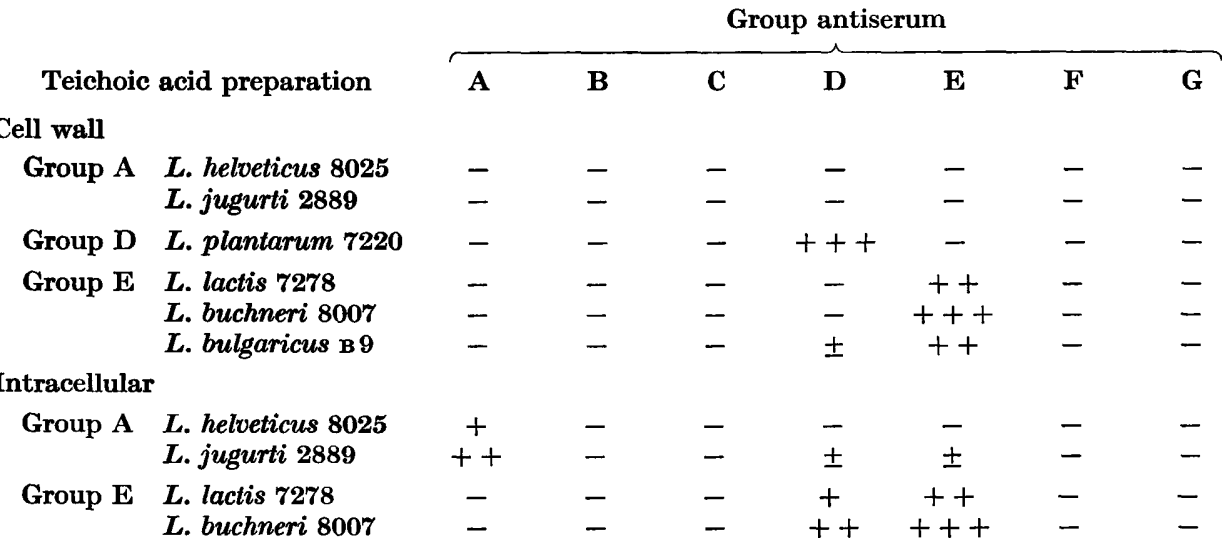

Positive reaction with teichoic acid concentration of $0.01 \mathrm{mg} . / \mathrm{ml} .,+++; 0.1 \mathrm{mg} . / \mathrm{ml} .,++$; $1.0 \mathrm{mg} . / \mathrm{ml} .$, + ; $1.0 \mathrm{mg} . / \mathrm{ml}$. (weak), \pm .

Gel-diffusion tests. Agar gel-diffusion tests confirmed and extended the results obtained with the ring precipitin tests. Group D antiserum, prepared against Lactobacillus plantarum A 164, gave precipitin lines of identity in agar with ribitol teichoic acid from the walls of $L$. plantarum NCIB 7220, and with antigen extracted with $\mathrm{HCl}$ from these and additional strains in group D. Group $\mathbf{E}$ antiserum prepared against $\boldsymbol{L}$. lactis NCIB $\mathbf{7 2 7 8}$ reacted in a similar manner with glycerol teichoic acids from walls of this strain of L. lactis, L. buchneri NCIB 8007, L. bulgaricus $\mathrm{B} 9$ and with $\mathrm{HCl}$ extracts of these and additional strains of $L$. lactis, $L$. bulgaricus and $L$. brevis from group $\mathrm{E}$; lines of identity occurred between all these preparations. The reactivity of material from strains of $\boldsymbol{L}$. bulgaricus with group $\mathrm{E}$ antiserum was somewhat weaker than that observed with teichoic acid from other organisms in group $\mathrm{E}$, but the lines of identity between preparations from $L$. buchneri, $L$. bulgaricus and $L$. lactis indicated that the group antigen was the same.

Teichoic acid from walls of the organisms in group $\mathbf{A}$ (Lactobacillus helveticus NCIB 8025 and $L$. jugurti $\mathrm{NCIB} 2889$ ) showed no reaction with group A antiserum prepared against $\boldsymbol{L}$. jugurti мсгв 2889. However, intracellular teichoic acid from the cell cytoplasm of those two strains, and acid extracts of these and other strains in group $\mathbf{A}$, gave lines of identity in agar with group $\mathbf{A}$ antiserum. The specific substance for group $A$ was therefore the intracellular teichoic acid and not the 


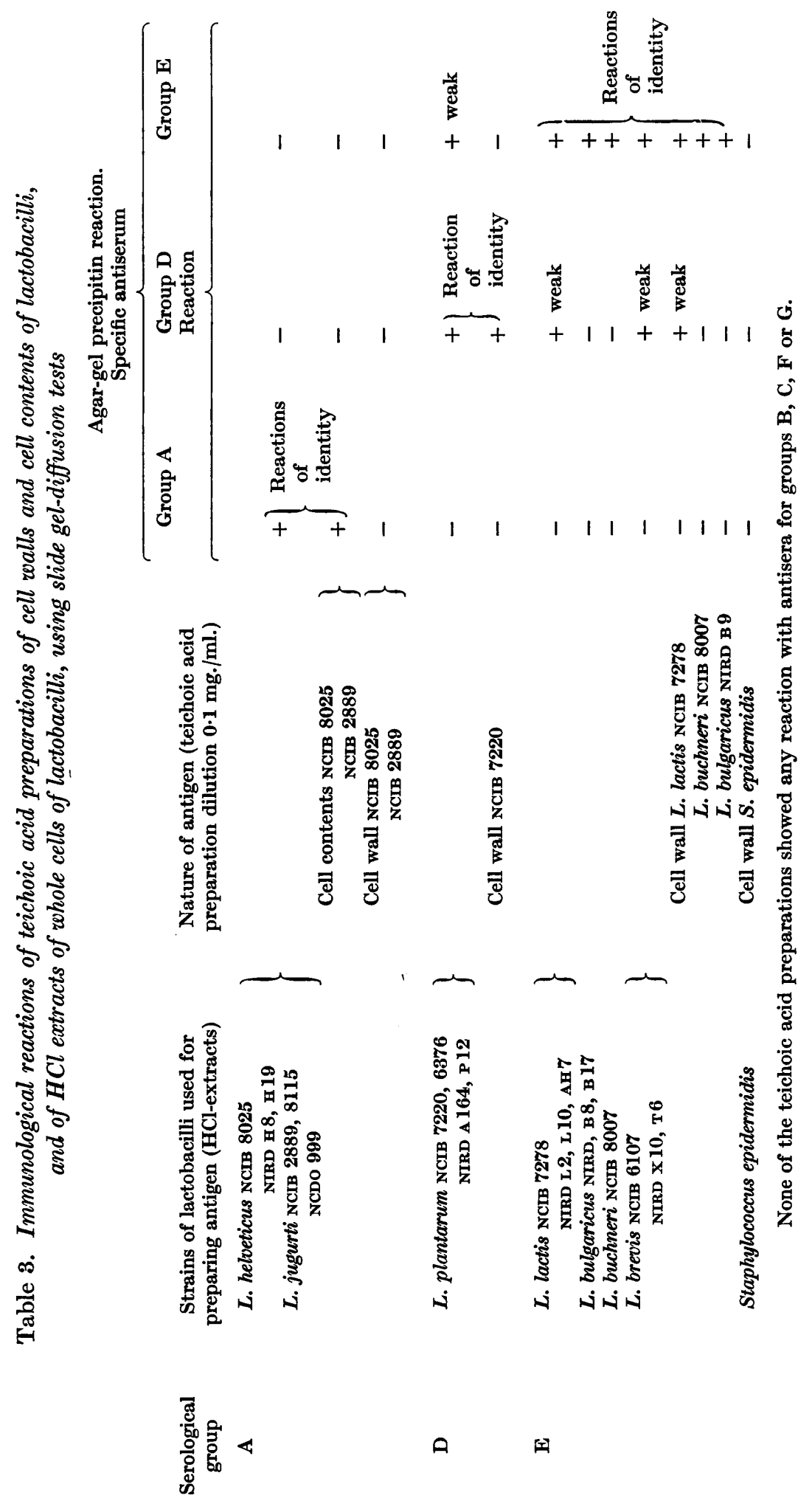


wall teichoic acid. Results are given in Table 3 ; reactions were specific in that teichoic acids from groups $\mathrm{A}, \mathrm{D}$ and $\mathrm{E}$ showed no reactivity with antiserum for groups B, C, F, or G, and all sera were negative when examined with a chemically similar teichoic acid from walls of Staphylococcus epidermidis.

\section{DISCUSSION}

Knowledge of the serological composition of lactobacilli enables their division in broad groups (Sharpe, 1955 b; Sharpe \& Wheater, 1957; Rogosa \& Sharpe, 1959). Satisfactory grouping sera are not, however, available for all species of lactobacilli and certain widely divergent species such as Lactobacillus lactis, L. bulgaricus on the one hand and $L$. brevis and $L$. buchneri on the other share the group $\mathbf{E}$ antigen. More detailed investigation of the chemical composition of teichoic acids in the walls of some species of lactobacilli (Baddiley \& Davison, 1961) has shown that walls of the homofermentative species, $L$. lactis and $L$. bulgaricus, and the heterofermentative species, $L$. brevis and $L$. buchneri, of group $\mathrm{E}$ have a chemically similar glycerol teichoic acid containing glucosyl residues. Moreover, the gel-diffusion reaction of identity of teichoic acid from these strains and group-specific material extracted with hydrochloric acid (Sharpe, 1955b) from whole organisms of these and additional strains in group $\mathbf{E}$ clearly indicates that the wall teichoic acid is the group E precipitinogen.

Similarly, ribitol teichoic acid from the single group D species Lactobacillus plantarum is the group substance. Teichoic acid from L. plantarum NCrB 7220 is structurally similar to that previously isolated from the walls of strain 17-5 by Archibald et al. (1961). Walls of this latter strain, however, contain a polysaccharide which was not found in strain 7220, and therefore presumably could be a typespecific component. Investigation of other strains in group $D$ is in progress. Some cross-reactions occurred between wall teichoic acid preparations from group $\mathrm{E}$ and antiserum for group D. Cross-reactions have previously been observed between group $\mathrm{E}$ antiserum and $\mathrm{HCl}$ extracts of organisms in group $\mathrm{D}$, and between group $\mathbf{D}$ antiserum and $\mathrm{HCl}$ extracts of organisms in group $\mathrm{E}$. The possibility that in these cases cross-reactions may be due to the intracellular teichoic acids is under investigation.

By contrast, the group A precipitinogen is the intracellular glycerol teichoic acid and not the wall teichoic acid. Intracellular teichoic acid from the group A species Lactobacillus helveticus and L. jugurti was atypical in its behaviour during isolation: it was not sedimented by centrifugation at $100,000 \mathrm{~g}$ as is the case with all other intracellular teichoic acids investigated (Davison \& Baddiley, 1963; RajBhandary \& Baddiley, 1963; Wicken, Elliott \& Baddiley, 1963; Critchley et al. 1962). The term 'intracellular' is used to indicate that these teichoic acids are not in the wall but are isolated from the cell contents fraction of disrupted organisms. In at least two cases these compounds are believed to be located between the wall and the protoplast membrane (Hay, Wicken \& Baddiley, 1963).

The absence of serological reactivity and the low sugar content of glycerol teichoic acid from walls of lactobacilli in group $\mathbf{A}$ indicate that appreciable amounts of sugar must be attached to a teichoic acid in order to confer immunological activity; moreover, with Lactobacillus spp. specificity must be partly dependent on 
glycosidic configuration, since a chemically similar glycerol teichoic acid possessing glucosyl residues from the walls of Staphylococcus epidermidis gave no reaction with group $\mathbf{E}$ or any other group antisera. Lactobacilli in groups B, C, F and G contain no wall teichoic acid and, whereas the group $B$ and $C$ precipitinogens are serologically distinct polysaccharides (Knox, 1963), preliminary evidence suggests that in group $\mathbf{F}$ intracellular teichoic acid could be the group-specific substance. It seems unlikely that purified teichoic acids would themselves engender an immunological response in vivo. They probably behave rather as haptenes and therefore are in that respect similar to the group-specific polysaccharides of streptococci of groups $\mathbf{A}$ and $\mathbf{C}$.

The serological, and possibly chemical, identity of teichoic acid preparations from the walls of lactobacilli in group E supports the suggestion (Davis, 1936) that the biochemically dissimilar members of the group may have had a common origin, and the differentiation of homofermentative and heterofermentative species into separate genera might be misleading (Rogosa et al. 1953). Thus, knowledge of the structure of wall and intracellular teichoic acids provides a useful method for the classification of these organisms and may assist in establishing relationships of groups which are not yet fully understood.

We thank the Nuffield Foundation and the Department of Scientific and Industrial Research for financial assistance.

\section{REFERENCES}

Archibald, A. R., Baddiley, J. \& Buchanan, J. G. (1961). The ribitol teichoic acid from Lactobacillus arabinosus walls. Biochem. J. 81, 124.

Armstrong, J. J., Baddiley, J., Buchanan, J. G., Carss, B. \& Greenberg, G. R. (1958). Isolation and structure of ribitol phosphate derivatives (teichoic acids) from bacterial walls. J. chem. Soc. p. 4344 .

Armstrong, J. J., Baddiley, J., Buchanan, J. G., Davison, A. L., Kelemen, M. V. \& Neuhaus, F. C. (1959). Composition of teichoic acids from a number of bacterial walls. Nature, Lond. 184, 247.

Baddiney, J. (1961). Immunological Approaches to Problems in Microbiology, p. 91. Ed. by M. Heidelberger, O. J. Plescia and R. A. Day. New York: Rutgers University Press.

Baddiley, J. \& Davison, A. L. (1961). The occurrence and location of teichoic acids in lactobacilli. J. gen. Microbiol. 24, 295.

Baddiley, J., Buchanan, J. G., RajBhandary, U. L. \& Sanderson, A. R. (1962a). Teichoic acid from the walls of Staphylococcus aureus H. Biochem. J. 82, 439.

Baddiley, J., Buchanan, J. G., Martin, R. O. \& RaJBhandary, U. L. (1962b). Teichoic acid from the walls of Staphylococcus aureus H. Biochem. J. 85, 49.

Barton-Wright, E. C. (1946). Practical Methods for the Microbiological Assay of Vitamin $B$ Complex and Essential Amino Acids. London: Ashe Laboratories.

Critchley, P., Archibald, A. R. \& Baddiley, J. (1962). The intracellular teichoic acid from Lactobacillus arabinosus 17-5. Biochem. J. 85, 420.

Davis, J. G. (1936). A procedure for the isolation and identification of the lactic acid bacteria. Proc. Soc. agric. Bact. 1936.

Davison, A. L. \& Baddiley, J. (1963). The distribution of teichoic acids in staphylococci. J. gen. Microbiol. 32, 271.

Fischer, F. G. \& Nebel, H. J. (1956). Detection and estimation of glucosamine and galactosamine on paper chromatograms. Analyt. Abstr. 3, 1101.

HAUKENES, G. (1962). Immunological studies on polysaccharide A of Staphylococcus aureus. Acta path. microbiol. scand. 55, 463. 
Haukenes, G., Ellwood, D. C., Baddiley, J. \& Oeding, P. (1961). Serological cross reactivity between polysaccharide $A$ and teichoic acid of Staphylococcus aureus. Biochim. biophys. Acta, 53, 425.

HAy, J. B., Wicken, A. J. \& BADdiley, J. (1963). The location of intracellular teichoic acids. Biochim. biophys. Acta, 71, 188.

IKaWA, M. \& SNeLL, E. E. (1960). Cell wall composition of lactic acid bacteria. J. biol. Chem. 235, 1376.

Jones, D. \& Shatrock, P. M. F. (1960). The location of the group D antigen of Group D streptococcus. J. gen. Microbiol. 23, 335.

Kelemen, M. V. \& BADdiley, J. (1961). Structure of the intracellular teichoic acid from Lactobacillus casei A.T.C.C. 7469. Biochem. J. 80, 246.

KNox, K. W. (1963). Isolation of group specific products from Lactobacillus casei and L. casei var. rhamnosus. J. gen. Microbiol. 31, 59.

Man, J. C. DE, Rogosa, M. \& Sharpe, M. E. (1960). A medium for the cultivation of lactobacilli. J. appl. Bact. 23, 130.

Morse, S. I. (1963). Isolation and properties of a group antigen of Staphylococcus albus. J. exp. Med. 117, 19.

Ouchterlony, O. (1953). Gel diffusion methods for immunological analysis. Atti 6 Congr. int. Microbiol. Roma, 2, 276.

RaJBhandary, U. L. \& Baddruex, J. (1963). The intracellular teichoic acid from Staphylococcus aureus H. Biochem. J. 87, 429.

Rogosa, M. \& Sharpe, M. E. (1959). An approach to the classification of the lactobacilli. J. appl. Bact. 22, 329.

Rogosa, M., Wiseman, R. F., Mitchell, J. A., Disraely, M. N. \& Beaman, A. J. (1953). Species differentiation of oral lactobacilli from man including descriptions of Lactobacillus salivarius nov.spec. and $L$. cellobiosus nov.spec. J. Bact. 65, 681 .

Sharpe, M. E. $(1955 a)$. Haptene substances in culture media for lactobacilli. J. gen. Microbiol. 13, 198.

Sharpe, M. E. (1955b). A serological classification of lactobacilli. J. gen. Microbiol. 12, 107.

Sharpe, M. E. \& Wheater, D. M. (1957). Lactobacillus helveticus. J. gen. Microbiol. 16, 676.

SмrтH, I. (1960). Chromatographic and Electrophoretic Techniques, vol. 1. London: William Heinemann Medical Books Ltd.

Wicken, A. J., ElliotT, S. D. \& Baddiley, J. (1963). The identity of streptococcal group $\mathrm{D}$ antigen with teichoic acid. J. gen. Microbiol. 31, 231. 